Research.

\title{
Analysis of consumer loyalty based on the aspect of brand image and after sales service
}

\author{
$1^{*}$ Indah Kusuma Hayati, ${ }^{2}$ Sumardjono, ${ }^{3}$ Yadi Mulyadi \\ Department of Management, Universitas Binaniaga Indonesia, Bogor, Indonesia \\ 1*indah.fadilah73@gmail.com, 2sdjonref18@gmail.com, 3.yadi.mulyadi1993@gmail.com \\ * Corresponding author
}

Received: March 20, 2020; Accepted: June 15, 2020; Published: June 30, 2020

To cite this article: Hayati, Indah Kusuma, Sumardjono, and Yadi Mulyadi. 2020. Analysis of consumer loyalty based on the aspect of brand image and after sales service. The Management Journal of BINANIAGA. 5 (1): 79-88. doi: $10.33062 / \mathrm{mj}$ b.v5i01.379

\begin{abstract}
Rapid economy development in Indonesia has created tight competitive business. Business people have to try very hard to make their business exist, they are obliged to be able to deal with competitive business keeping the consumers to be loyal. Because consumers are the most important asset for a company. And a company will jeopardize its business if it does not have any consumers. The way how to keep the consumers loyal to the company is thru Brand Image and After Sales Service. This research aims to figure out the extent to which Brand Image and After Sales Service have affected Consumer Loyalty. And Objects of this research are furniture consumers at PT Informa Bogor. Data analysis has applied multiple linear regression analysis, determinant coefficient, $F$ test and $T$ test to test the hypotheses. The result of $F$ test has identified Brand Image and After Sales Service affecting significantly Consumer Loyalty. Partial test has identified independent variables partially affecting significantly Consumer Loyalty. Nevertheless, the contribution of independent variable to the increasing Consumer Loyalty is quite small which is $36.5 \%$, and the rest has been affected by other factors which are not studied in this research.
\end{abstract}

Keywords: Consumer Loyalty, Brand Image, and After Sales Service

\section{INTRODUCTION}

\section{Background}

Rapid economy development in Indonesia has created competitive business. Each business people have to work hard to keep their existence, they are required to be able to keep their consumers competitively. Consumers are the most important asset of a company. A company will be difficult to develop or to survive if it does not have any consumers. Some efforts to keep the consumers' loyalty are thru Brand Image and excellent customer service.

Brand of the product is brand image in the community that will receive priority in the market. Brand image is a kind of belief, idea and image owned by the people upon a certain brand, therefore, attitude and behavior and action of the customers about a certain product are determined by Brand Image of the product itself. Brand Image is the requirement of being strong brand (Kotler, 2008:32) product that is having positive brand image will impact the possibility of the consumers identifying the products that are able to meet their requirement and they will compare with other product. Finally, it will affect the willingness to buy the product. 
Superior service is another factor determining the success of a company. Tight competition is required by the company to provide best customer service to the customer either at the process of purchasing or after purchasing. Superior service should have to be done at any circumstances. It will produce the willingness to buy of the customer and to repurchase the product or the service.

\section{Problem Designs}

1. Is Brand Image affecting Customers Loyalty?

2. Is After Sales Service affecting Customers Loyalty?

3. Are Brand Image and After Sales Service simultaneously affecting Customers Loyalty?

\section{LIBRARY REVIEW}

\section{Brand Image}

Kotler and Keller (2013:82) "Brand Imagery describe the extrinsic properties of the product or service, including the ways in which the brand attempts to meet customers psychological or social needs". And Kotler and Armstrong (2014:233) defined brand image is "The set of belief held about a particular brand is known as brand image". Durianto written on Sangadji and Sopiah (2013:329-331) determined that brand association is developed by three elements:

1. Preceived Value, is the customer's perception upon a product based on price spending by the customer comparing to the benefit of using the products. 5 (five) aspects of the value perceived by the customer consisting of quality of the product, price, service quality, emotional factor and easiness.

2. Brand Personality, Emotional brand relatedness refers to the benefit of using the product.

3. Organization Association, will be the most important factor when the brand is similar with another brand, or when the organization is something very important to be associated.

\section{After Sales Service}

Referring to Barata (2003:30) described, service is a kind of activity or a set of activities happened in a direct interaction between a person with another one or machine physically, and provides customers satisfaction. A service to the customer is keeping the customer trust and satisfaction upon the product or brand. Superior service can be done during the purchasing or after sales service. After sales service aims to (1) maintain the willingness to buy of the consumers. (2) provide customers' satisfaction. (3) create trust and reputation. (4) provide guarantee with certain requirement openly. After Sales Service is the responsibility of business people, seller upon the quality of their product, and is continuous activities providing spare parts change and reparation.

\section{Consumers Loyalty}

According to Hasan (2014:121), consumers loyalty is a behavior related to a brand of the product, including the renewal of brand contract in the future, the extent to which the consumers will change their brand support and will improve positive brand image of the product. But according to Griffin (2005:5), Concept of Consumer Loyalty is mostly related to a behavior rather than attitude. If a customer is loyal, he indicates purchasing behavior which is defined as nonrandom purchasing continuously some units.

It is supported by Griffin description (2005:31) described that some characteristics of loyal customers are as follow:

1. Repeat purchase regularly.

2. Purchase all products line or services.

Indah Kusuma Hayati, Sumardjono, and Yadi Mulyadi. Analysis of consumer loyalty based on the aspect of brand image and after sales service 
3. Recommend other product.

4. Invulnerable to similar products from the competitor.

\section{Research Design and Hypotheses}

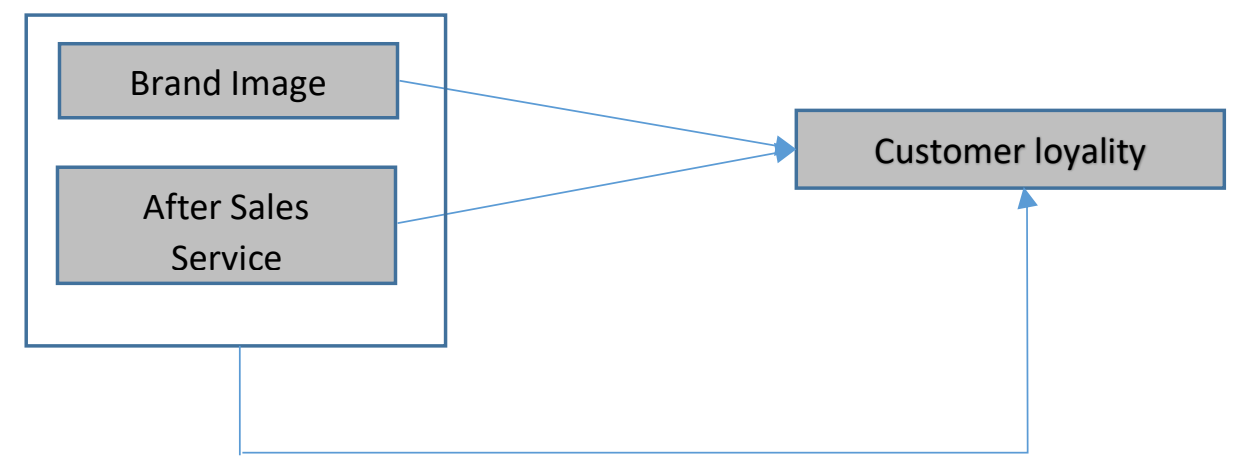

\section{Hypotheses}

Hypothesis 1: Brand Image has affected Customer Loyalty.

Hypothesis 2: After Sales Service has affected Customers Loyalty.

Hypothesis 3: Brand Image and After Sales Service simultaneously have affected positively Customers Loyalty.

\section{RESEARCH METHODOLOGY}

\section{Research Variables and Operational Definition}

Variables of this research are Brand Image and After Sales Service as independent variables and Consumers Loyalty as dependent variable. According to the conceptional definition, both variables are described on theoretical study and have designed operational definition as follow:

1. Brand Image variable is the perception of customers associated with the product. And the indicators of Brand Image variable are:
a. Preceived Value;
b. Brand Personality, and
c. Organizational Association.

2. After Sales Service is business people or seller responsibility for the product quality and is a continuous activity such as spare parts change, repairing. Indicators of After Sales Service variable are as follow:
a. Guarantee.
b. Repair service.
c. Spare parts.

3. Loyalty of the consumers is indicated by regular repurchasing product based on the decision to get the unit. Indicators of Consumers Loyalty variable are as follow:
a. Regular repurchasing the product.
b. Purchasing all product line or service.
c. Recommending other products.
d. Invulnerable to the similar products from the competitor. 


\section{Sampling Method}

Population of this research are furniture consumers at PT Informa in Bogor. Because the population are not determined, the samples required are influenced by maximum error (i) and degree of trust to identify the population. So that total of the samples is indicated as follows (Aaker and Kumar, 20120:53):

$$
\mathrm{n}=\frac{\mathrm{Z}^{2} \mathrm{p}(1-\mathrm{p})}{(\mathrm{i})^{2}}
$$

$\mathrm{n}$ is total samples, $\mathrm{p}$ is population proportion and $\mathrm{Z}$ is $\mathrm{Z}$ score at a certain degree of trust and $\mu$ is sampling error. $P$ value is always between $0-\sim$ and $p$ value $(1-p)$ can be identified as follow:

$$
\begin{aligned}
& \text { If } p=p(1-p) \\
& P=p-p^{2} \\
& P \text { maximum if } \\
& =\frac{d p}{d p}=0 \\
& 1-2 p=0 \\
& p=0,5
\end{aligned}
$$

Substitute $p$ value into the sample equation to get :

$\mathrm{n}=\frac{\mathrm{Z}^{2} 0,5(1-0,5)}{\mu^{2}}$

$\mathrm{n}=\frac{\mathrm{Z}^{2}}{4 \mu^{2}}$

If the degree of trust is defined $95 \%$, it is having the degree of error $5 \%$ (Alpha $/ 2=$ 0.025 producing $Z$ table of 1.96 ) and $\mu$ value of $10 \%$ having $Z$ value of 1.96 , producing the following samples:

$\mathrm{n}=\frac{(1,96)^{2}}{4(0,1)^{2}}=\frac{3,8416}{4(0,1)}=96,04=100$

So that, the samples of this research is 96.04 or rounded to 100 respondents (samples).

Sampling technique is applied Accidental Sampling. Accidental sampling is a technique to identify the sample unexpectedly, everyone accidentally meets the researcher and is meeting the data resources (Sugiyono, 2013:67).

\section{Method of Data Analysis}

\section{Classical Assumption Test}

\section{a. Normality Test}

According to Sujianto (2009:79), Normality test is to measure whether the data are distributed normal and can be used in statistics parameter. One of the methods that can be applied to detect normality matter is Kolmogorov-Smirnov test which is to figure out whether the samples are from the population distributed normal, however, if its significance value is $>0.05$, the data are distributed normal.

\section{b. Multicollinearity Test}

Multicollinearity test is to test whether in the regression model has indicated high correlation between independent variables (Ghozali, 2013) Multicollinearity test has identified tolerance value and Variance Inflation Factor (VIF) value. Tolerance 
value of $>0.10$ and VIF value of $<10.0$ have identified that there is not any multicollinearity happened.

\section{c. Heteroscedasticity Test}

Heteroscedasticity is testing the difference of residual variance happened during each period of the research, or it is designing the relationship between predicted value and Studentized Delete Residual value. Good regression model is a regression model having similar residual variance during the observation periods, or a relationship between the predicted value and Studentized Delete Residual value indicated that the model is homocesdasticity.

\section{Multiple Regression Analysis}

According to Sunyoto $(2012: 139)$ described that multiple regression analysis is to indicate the effect of two or more independent variables $\left(X_{1}, X_{2}, X_{3} \ldots \ldots . . X_{n}\right)$ upon the dependent variable $(\mathrm{Y})$.

$$
Y=\beta_{1} X_{1}+\beta_{2} X_{2}+e
$$

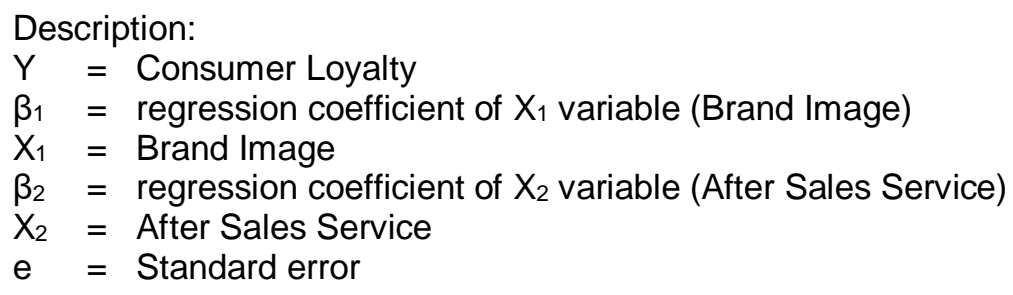

\section{Hypotheses Test}

\section{a. F test}

$\mathrm{F}$ test is applied to test hypotheses of the research by applying multiple linear regression analysis. $F$ test is applied to figure out the effect of independent variables simultaneously upon dependent variable.

\section{b. Partial Test (T test)}

$\mathrm{T}$ test is to test one of the hypotheses of the research using multiple linear regression analysis. T test is applied to test each variable partially.

\section{Determinant Analysis}

This test is to define the proportion or percentage of varied total of dependent variable which is described by independent variables. If the analysis is using simple regression, $R$ square value will be applied. But, if the analysis is using multiple regression, Adjusted $\mathrm{R}$ Square will be applied.

\section{RESULT AND DESCRIPTION}

Result

\section{Classical Assumption Test}

\section{Normality Test}

Normality rest is to test whether in the regression model of independent variables and dependent variable, both, are having normal distribution or nearly normal. Data will be distributed normal if sig. value (significant) is more than 0.05 , on the table 1 has indicated significant value of After Sales Service of $0.287>0.05$, sig. value of brand image of $0.165>0.05$, sig. value of consumer loyalty of $0.177>0.05$ (table 1 ). 
Table 1

One-Sample Kolmogorov-Smirnov Test

\begin{tabular}{|ll|r|r|r|}
\hline & & $\begin{array}{c}\text { Pelayanan } \\
\text { Purna Jual }\end{array}$ & Citra Merek & $\begin{array}{c}\text { Loyalitas } \\
\text { Konsumen }\end{array}$ \\
\hline N & 100 & 100 & 100 \\
Normal & Mean & 25,21 & 25,70 & 25,24 \\
Parameters & Std. Deviation & 2,430 & 2,204 & 1,913 \\
\hline Most Extreme $\quad$ Absolute &, 098 &, 112 &, 110 \\
Mifferences $\quad$ Positive &, 098 &, 095 &, 100 \\
& Negative &,- 097 &,- 112 &,- 110 \\
Kolmogorov-Smirnov Z &, 984 & 1,116 & 1,101 \\
Asymp. Sig. (2-tailed) &, 287 &, 165 &, 177 \\
\hline a. Test distribution is Normal. \\
b. Calculated from data.
\end{tabular}

\section{Multicollinearity Test}

Multicollinearity test has indicated that the three independent variables are having tolerance value of bigger than 0.1 and VIF of less than 10.0. it has explained that multicollinearity matter is not happened.

Table 2, based on the table above, it has indicated the variable having VIF value of 1.015 but less than 10 and tolerance value of 0.985 . It is describing that independent variables used in this research are not indicating any multicollinearity matter.

Table 2

Hasil Uji Normalitas

Coefficients $^{\mathrm{s}}$

\begin{tabular}{|c|c|c|c|c|c|c|c|}
\hline \multirow[t]{2}{*}{ Model } & \multicolumn{2}{|c|}{$\begin{array}{l}\text { Unstandardized } \\
\text { Coefficients }\end{array}$} & \multirow{2}{*}{$\begin{array}{c}\begin{array}{c}\text { Standardi } \\
\text { zed } \\
\text { Coefficie } \\
\text { nts }\end{array} \\
\text { Beta }\end{array}$} & \multirow[t]{2}{*}{$\mathrm{T}$} & \multirow[t]{2}{*}{ Sig. } & \multicolumn{2}{|c|}{$\begin{array}{c}\text { Collinearity } \\
\text { Statistics }\end{array}$} \\
\hline & B & Std. Error & & & & \begin{tabular}{|c} 
Tolera \\
nce
\end{tabular} & VIF \\
\hline (Constant) & 8,117 & 2,263 & & 3,587 & .001 & & \\
\hline $\begin{array}{l}\text { Pelayanan Purna } \\
\text { Jual }\end{array}$ &, 352 &, 064 & ,448 & 5,547 &, 000 & ,985 & 1,015 \\
\hline Citra Merek & 321 &, 070 & 369 & 4,576 &, 000 & ,985 & 1,015 \\
\hline
\end{tabular}

\section{Heteroscedasticity Test}

Heteroscedasticity is testing the difference of residual variance of one period of observation with another period of observation, or the picture of the relationship between the predicted value and Studentized Delete Residual value. Based on the output data above, it is indicated that plots are not producing a clear pattern, and the plots are scattering above and under 0 at $Y$ axis. Therefore, it is determined that there is not any heteroscedasticity happened in the regression model (Figure 1).

Indah Kusuma Hayati, Sumardjono, and Yadi Mulyadi. Analysis of consumer loyalty based on the aspect of brand image and after sales service 


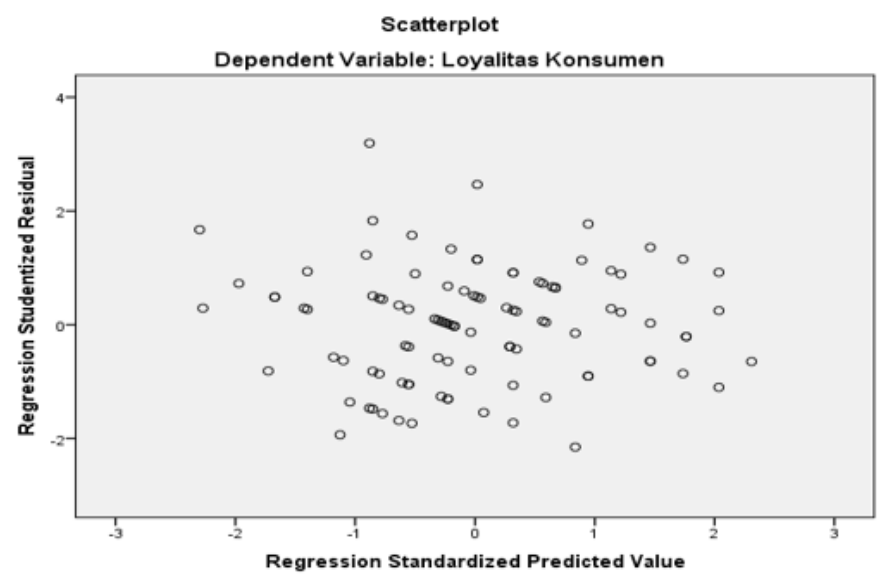

Figure 1

\section{Multiple Regression Analysis}

Table 3

Result of Multiple Analysis Test

\begin{tabular}{|c|c|c|c|c|c|}
\hline \multirow[t]{2}{*}{ Model } & \multicolumn{2}{|c|}{$\begin{array}{c}\text { Unstandardized } \\
\text { Coefficients }\end{array}$} & $\begin{array}{l}\text { Standardized } \\
\text { Coefficients }\end{array}$ & \multirow[t]{2}{*}{$t$} & \multirow[t]{2}{*}{ Sig. } \\
\hline & $\mathrm{B}$ & Std. Error & Beta & & \\
\hline (Constant) & 8,117 & 2,263 & & 3,587 & 001 \\
\hline Brand Image &, 321 &, 070 & ,369 & 4,576 &, 000 \\
\hline After Sales Service &, 352 & 064 & 448 & 5,547 & 000 \\
\hline
\end{tabular}

a. Dependent Variable: Consumer Loyalty

Referred to the table above, it has indicated the equation of multiple linear regression analysis as the following:

$$
Y=8.117+0.321 X_{1}+0.352 X_{2}
$$

a. Constant value is positive which is 8.117, if variables of Brand Image and After Sales Service are considered constant, but they are influenced by the variables excluded the model, therefore, it is assumed that Consumer Loyalty will increase to 8.117 units.

b. Regression coefficient value of Brand Image $\left(X_{1}\right)$ is positive which is 0.321 , this figure is indicating that if the assumption of perception value of After Sales Service variable is constant and Brand Image variable is increased to 1 unit of Brand Image, it will increase Consumer Loyalty of 0.321 .

c. Regression coefficient value of After Sales Service $\left(X_{2}\right)$ is positive which is 0.352 , this figure is indicated that the assumption of perception value of Brand Image variable is constant and After Sales Service is increased to 1 unit, it is predicted that Consumer Loyalty will increase 0.352 .

\section{Hypotheses Test}

\section{a. Partial Test}

This test is to compare tcount value with table which is described on the coefficient table, but table is described on table $t$ student which is at degrees of freedom (df) of 98 (total of the data reduced by total variable), and at sig. of $5 \%$, so that value of table is 1.984 . The Hypothesis is accepted if $t_{\text {count }}>t_{\text {table. }}$ 
Table 3 has indicated that Brand Image variable indicating Tcount value of 4.576, this figure is bigger than 1.984. It is describing that Brand Image has affected significantly and partially Consumer Loyalty. And After Sales Service variable has indicated Tcount of 5.547 which is bigger than 1.984 it is describing that After Sales Service has affected significantly and partially Consumer Loyalty.

\section{b. F test simultant test}

Table 4

Anova Test

\begin{tabular}{|l|r|r|r|r|r|}
\hline \multicolumn{1}{|c|}{ Model } & Sum of Squares & df & Mean Square & F & \multicolumn{1}{c|}{ Sig. } \\
\hline Regression & 136,790 & 2 & 68,395 & 29,427 &, $000^{\mathrm{b}}$ \\
\hline Residual & 225,450 & 97 & 2,324 & & \\
\hline Total & 362,240 & 99 & & & \\
\hline
\end{tabular}

a. Dependent Variable: Consumer Loyalty

b. Predictors: (Constant), Brand Image, After Sales Service

Table 4 above. Anova table has indicated $F_{\text {count }}$ of 29.427 and degrees of significant of 0.000 . So that, if sig.degrees of $0.000<0.05$ and $(n-k-1)$ or $100-2-1=$ 97 it produces $F_{\text {table }}=3.94$. Nevertheless, value of $F_{\text {count }}>T_{\text {table }}$ or $29.427>3.94$. It means that Hypothesis $3\left(\mathrm{H}_{3}\right)$ is accepted: Brand Image and After Sales Service simultaneously have affected significantly Consumer Loyalty.

\section{Determinant $\left(R^{2}\right)$ Analysis}

\section{Table 5}

\begin{tabular}{|c|r|r|r|r|r|r|r|r|r|}
\hline \multicolumn{10}{|c|}{ Model Summary } \\
\hline \multirow{2nnnyyyyyy}{*}{ Model } & $R$ & $R$ & $\begin{array}{c}\text { Adjusted R } \\
\text { Square }\end{array}$ & $\begin{array}{c}\text { Std. Error } \\
\text { of the } \\
\text { Estimate }\end{array}$ & $\begin{array}{c}\text { R Square } \\
\text { Change }\end{array}$ & F Change & df1 & df2 & $\begin{array}{c}\text { Sig. F } \\
\text { Change }\end{array}$ \\
\hline 1 &, $615 \mathrm{a}$ &, 378 &, 365 & 1,525 &, 378 & 29,427 & 2 & 97 &, 000 \\
\hline \multicolumn{2}{|c|}{ a. Predictors: (Constant), Brand Image, After Sales Service } \\
\hline
\end{tabular}

Table 5 has indicated Adjusted R Square value of 0.365 . Adjusted $R$ Square and determinant coefficient has produced $36.5 \%$ indicating that contribution percentage of the effect independent variables (Brand Image and After Sales Service) have affected $36.5 \%$ upon Consumer Loyalty. But $63.5 \%$ is affected by other variables which are not included in this this research.

\section{Description}

Result of the research has indicated that Brand Image has affected Consumer Loyalty at PT Informa Bogor. The connection between Brand Image and Consumer Loyalty was studied by former researcher, Indra Wijayanto and Sri Setyo Iriani (2013) at Starbuck Coffee and the research indicated that independent variable, Brand Image had affected significantly Consumer Loyalty. According to Shimp et al. in Sangadji and Sopiah (2012:327) brand image could be considered as association appearing in the consumer's mind when he remembers a certain brand. Good Brand Image will impact positively the company since it makes the customers satisfied and is able to attract the customers intention tot the product and will improve Consumers Loyalty accordingly.

According to Kotler in Ernoputri (2016:81) After Sales Service is best support for the company to provide After Sales Service which is moving thru some steps. Based on the definition of After Sales Service, a company can make the customers satisfied after 
purchasing the product or the service. It means, After Sales Service guarantees the customers to use the product or service. However, the company eagers to provide best service to the customer to create a good relationship between company and the customers continuously. Providing best service will make the customers repurchase the product and they will be loyal to the company. This research has indicated that After Sales Service has affected Consumers Loyalty at PT Informa Bogor. This research is getting along with the research of Rizky Tri Nopanti and Saefudin Zuhdi (2012) at PT Astra Internasional Tbk, Bogor branch and the result indicated strong and positive relationship between After Sales Service and Customers Loyalty significantly.

Simultaneous test has indicated that Brand Image has affected Consumers Loyalty at PT Informa. But the contribution of both variables has indicated $36.5 \%$ to Consumers Loyalty, and the remaining of $63.5 \%$ indicated by other factors such as, price, product quality, etc.

\section{CONCLUSION}

1. According to the result of regression equation, it has indicated that the prediction of the effect of Brand Image and After Sales Service upon Consumer Loyalty is positive. It has explained that the two variables have affected positively Consumer Loyalty.

2. According to the criteria of determinant coefficient interpretation, it has indicated that the contribution of Brand Image and After Sales Service to Consumer Loyalty is quite low. However, other unidentified factors have affected significantly Consumer Loyalty at PT Informa Bogor.

3. According to the result of the research, simultaneously Brand Image and After Sales Service have affected significantly Consumer Loyalty at PT Informa Bogor.

4. Based on the partial research, Brand Image or After Sales Service partially has affected significantly Consumer Loyalty at PT Informa Bogor.

\section{REFERENCES}

Aaker, David A. Kumar, V. Day, George S., 2010, Marketing Research 9 Edition. John Wiley \& Sons, Danvers. Page: 53.

Barata, Atep Adya. (2003). Dasar-Dasar Pelayanan Prima. Jakarta : PT Gramedia Pustaka. Hal: 30.

Ernoputri, Darayani., Arifin, Zainul., Fanani, Dahlan. 2016. Pengaruh Layanan Purna Jual Terhadap Kepuasan Konsumen (Survei pada Pengguna Produk LG di Malang Town Square (Matos) Malang, Jawa Timur). Vol. 30 No. 31: Jurnal Administrasi Bisnis (JAB).

Ghozali, Imam. 2013. Aplikasi Analisis Multivariate dengan Program IBM SPSS 21. Edisi Ketujuh. Semarang: Badan Penerbit Universitas Diponegoro.

Griffin, Jill, 2005. Customer Loyalty: Menumbuhkan dan Mempertahankan Kesetiaan Pelanggan, Erlangga, Jakarta. Hal:5 - 31.

Hasan, Ali. 2014. Marketing dan Kasus-Kasus Pilihan. Jakarta: CAPS. Hal: 121.

Kotler, Philip \& Gerry Armstrong. 2014. Principle Of Marketing, 15th edition. New Jersey: Pearson Pretice Hall. Page:233.

Kotler, Philip and Keller, Kevin Lane. 2013. Manajemen Pemasaran, Jilid 1, Edisi 13, Erlangga. Hal:82.

Indah Kusuma Hayati, Sumardjono, and Yadi Mulyadi. Analysis of consumer loyalty

based on the aspect of brand image and after sales service 
The Management Journal of BINANIAGA Vol. 05, No. 01, June 2020

p-ISSN: $2527-4317$, e-ISSN: $2580-149 x$

$6^{\text {th }}$ Accreditation Rating: April 04, $2019-$ April 03, 2024

Sangadji, E.M., dan Sopiah. 2013. Prilaku Konsumen: Pendekatan Praktis Disertai: Himpunan Jurnal Penelitian. Yogyakarta: Penerbit Andi. Hal: 329-331.

Sugiyono, 2013, Metode Penelitian Bisnis. Cetakan Kesembilan, Alfabeta Bandung. Hal: 67.

Sujianto, Agus Eko. 2009. Aplikasi Statistik dengan SPSS 16.0. Jakarta: PT. Prestasi Pustakarya. Hal 94. 